\title{
A High Efficiency Ultrathin CdTe Solar Cell for Nano-Area Applications
}

\author{
Saeid Marjani' ${ }^{1}$, Saeed Khosroabadi², Masoud Sabaghi ${ }^{3}$ \\ ${ }^{1}$ Department of Electrical Engineering, Ferdowsi University of Mashhad, Mashhad, Iran \\ ${ }^{2}$ Department of Electrical Engineering, Imam Reza International University, Mashhad, Iran \\ ${ }^{3}$ Laser and Optics Research School, Nuclear Science and Technology Research Institute (NSTRI), Atomic Energy \\ Organization of Iran, Tehran, Iran \\ Email: *msabaghi@aeoi.org.ir
}

Received 26 December 2015; accepted 14 February 2016; published 17 February 2016

Copyright (C) 2016 by authors and Scientific Research Publishing Inc.

This work is licensed under the Creative Commons Attribution International License (CC BY).

http://creativecommons.org/licenses/by/4.0/

(c) () Open Access

\begin{abstract}
Due to limited availability and the rising price of telluride, the biggest challenge in solar Photovoltaic (PV) is to successfully design and fabricate optimized CdTe solar cells with reducing the cell thickness that show simultaneously high efficiency and current density. A novel structure of ultrathin CdTe solar cells is proposed in this paper that focuses on conversion efficiency. This structure achieved by rotating $90^{\circ}$ in the base line structure that suggests high efficiency due to the high current density. The result showed a considerable improvement over the $15 \%$ efficiency of the reference solar cell. The proposed structure is quite noteworthy in reducing the amount of material used and associated losses. Under global air mass (AM) 1.5 conditions, an open-circuit voltage $\left(V_{o c}\right)$ of $866 \mathrm{mV}$, a short-circuit current density $\left(J_{s c}\right)$ of $74.84 \mathrm{~mA} / \mathrm{cm}^{2}$, and a fill factor (FF) of $48.2 \%$ were obtained corresponding to a conversion efficiency of $31.2 \%$.
\end{abstract}

\section{Keywords}

CdS/CdTe Solar Cell, Conversion Efficiency, Nano-Area Applications

\section{Introduction}

Because of greater potential in low cost, high efficiency and stable solar cell fabrication, thin film polycrystalline CdS/CdTe solar cells are one of the most promising candidates for photovoltaic energy conversion in recent years. The CdTe has long been a leading material in thin film solar cell fabrication due to high optical absorption coefficient and ideal band gap of $1.45 \mathrm{eV}$. The most important parameter that affects photon absorption is

${ }^{*}$ Corresponding author. 
thickness of the CdTe layer [1]-[4]. Due to limited availability and the rising price of Te with regards to very high volume photovoltaic module manufacture in the future, reducing the CdTe absorber layer thickness is an attractive prospect. Another advantage is that overall material consumption will decrease along with module production costs. Avoiding pin-hole formation and maintaining the photocurrent generation are the challenges in using ultrathin absorber layers. One of suitable materials for window layer of CdS/CdTe solar cells is CdS film. Thinner CdS films cause higher $\mathrm{J}_{\mathrm{sc}}$ [3]-[6]. 28\% - 30\% are the maximum theoretical efficiency for CdTe solar cells [7] [8]. In the last 17 years, cell efficiency of CdTe solar cells has been increased by only 1.5\% [9]-[13]. The reported maximum cell efficiencies for the CdTe solar cells were between $16 \%$ and $16.5 \%$ [14]-[17]. The NREL verified cell efficiency of $20.4 \%$ and a module efficiency of $14 \%$ were reported by First Solar [18]. One of the current hot research topic and the challenge facing the researchers in the CdS/CdTe thin film solar cells is increasing efficiency and decreasing the gap between the actual efficiency and the theoretical limit.

In this paper, an ultrathin structure of CdTe solar cells has been proposed with high conversion efficiency for nano-area applications [19]-[30]. This new structure has achieved by rotating in the base line structure. The paper is organized as follows: Section 2 describes the analysis of conventional and proposed structures; and its validation. Section 3 presents the obtained numerical results and discussion. Finally, in Section 4, we conclude.

\section{Analysis of Conventional and Proposed Structures, and Its Validation}

The useful tool to analyze the solar cell performances is numerical modeling. The mechanism of such structures could be evaluated by numerical simulations enabling the design of new structures with better efficiency and stability. The starting point of this work was the baseline case as reported in [16]. In brief, the CdTe device model in the base line case consists of a $4 \mu \mathrm{m}$-thick CdTe absorber layer, a 100-nm thick CdS window layer, and a 500 -nm-thick $\mathrm{SnO}_{2}$ buffer layer. Most of the important electronic parameters are listed in Table 1 . The values have been chosen on the basis of theoretical considerations, experimental data and existing literature.

The energy of back barrier in CdTe layer was low about $0.3 \mathrm{eV}$. It is assumed that $5 \%$ of the incident light was reflected at the front contact. The electron lifetime of $0.5 \mathrm{~ns}$ was used in the CdTe absorber layer of the baseline case. Using the mentioned parameters, the baseline solar cell parameters were $\mathrm{V}_{\text {oc }}=0.865 \mathrm{~V}, \mathrm{~J}_{\mathrm{sc}}=25$ $\mathrm{mA} / \mathrm{cm}^{2}, \mathrm{FF}=73 \%$, and $\eta=15.7 \%$. At the next step, this structure was modified by rotating $90^{\circ}$ of the structure without dimension variation. Figure 1 illustrates the CdTe baseline case structure and the modified structures investigated in this study.

The proposed structure has many advantages such as high photogeneration and low recombination rate. The $\mathrm{J}_{\mathrm{sc}}$ of the cell can be improved by reducing the carrier recombination losses at the back contact or increasing the photogeneration rate in the absorber layer. Because the light inters to layers independently, the photogeneration rate is high in each layer. Figure 2 shows the comparison the photogeneration rate between conventional and proposed structure.

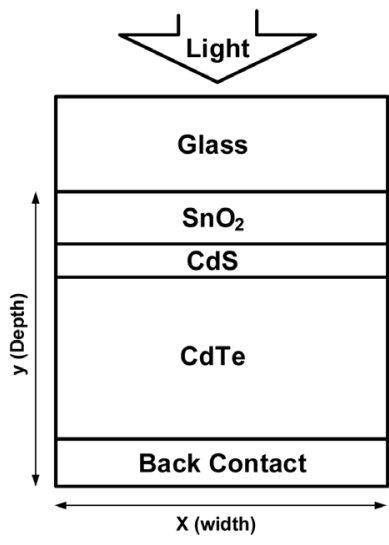

(a)

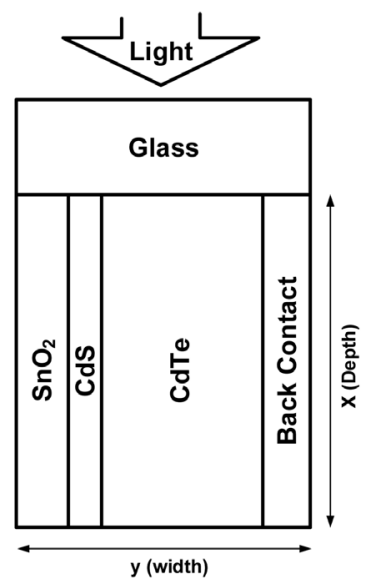

(b)

Figure 1. Structures of the CdTe solar cells: (a) baseline case structure and (b) modified cell structure for higher efficiency. 


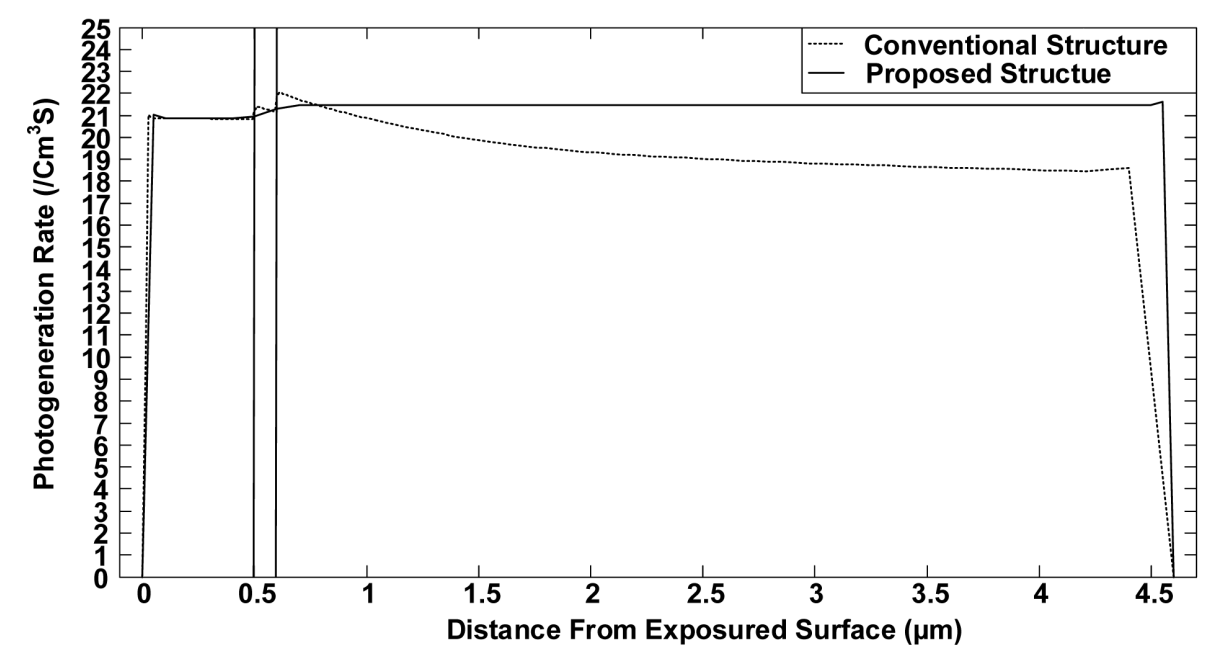

Figure 2. Photogeneration rate for the conventional and proposed structure.

Table 1. Best cell parameters including layer properties and defect states.

\begin{tabular}{|c|c|c|c|}
\hline Parameters Unit & CdS & $\mathrm{SnO}_{2}$ & CdTe \\
\hline Layer Width D [nm] & 100 & 500 & 4000 \\
\hline Dielectric Constant $\varepsilon / \varepsilon_{0}$ & 10 & 9 & 9.4 \\
\hline Electron Mobility $\mu_{\mathrm{e}}\left[\mathrm{cm}^{2} / \mathrm{Vs}\right]$ & 100 & 100 & 320 \\
\hline Hole Mobility $\mu_{\mathrm{h}}\left[\mathrm{cm}^{2} / \mathrm{Vs}\right]$ & 25 & 25 & 40 \\
\hline Electron/Hole Density $\mathbf{n , p}\left[\mathrm{cm}^{-3}\right]$ & $\mathrm{n}: 10^{17}$ & $\mathrm{n}: 10^{18}$ & $\mathrm{p}: 2 \times 10^{14}$ \\
\hline Band Gap Energy $E_{g}[e V]$ & 2.4 & 3.6 & 1.5 \\
\hline Effective Density of States $N_{C}\left[\mathrm{~cm}^{-3}\right]$ & $2.2 \times 10^{18}$ & $2.2 \times 10^{18}$ & $8 \times 10^{17}$ \\
\hline Effective Density of States $N_{V}\left[\mathrm{~cm}^{-3}\right]$ & $1.8 \times 10^{19}$ & $1.8 \times 10^{19}$ & $1.8 \times 10^{18}$ \\
\hline Acceptor/Donor Defect Density $\mathrm{N}_{\mathrm{DG}}, \mathrm{N}_{\mathrm{AG}}\left[\mathrm{cm}^{-3}\right]$ & A: $10^{17}$ & A: $10^{15}$ & D: $2 \times 10^{14}$ \\
\hline Defect Peak Energy $E_{A}, E_{D}[e V]$ & Midgap & Midgap & Midgap \\
\hline Distribution Width $\mathrm{W}_{\mathrm{G}}[\mathrm{eV}]$ & 0.1 & 0.1 & 0.1 \\
\hline Electron Capture Cross Section $\sigma_{\mathrm{e}}\left[\mathrm{cm}^{2}\right]$ & $10^{-17}$ & $10^{-15}$ & $10^{-12}$ \\
\hline Hole Capture Cross Section $\sigma_{\mathrm{h}}\left[\mathrm{cm}^{2}\right]$ & $10^{-12}$ & $10^{-12}$ & $10^{-15}$ \\
\hline
\end{tabular}

One of the main goals of today's solar cell research is using less semiconductor material by making the cells thinner. The thinning saves material and reduces the recombination loss as well as lower production time and the energy need to produce them. Therefore, all of these factors will decrease the production cost. Hence, it is possible to reduce the dimension of proposed structure considerably and achieve better base line results, simultaneously. Figure 3 shows the current-voltage and power-voltage curves for comparison with the base line case. As can be seen from Figure 3, the conversion efficiency can be increased to 31.2\% mostly due to improvement of $\mathrm{J}_{\mathrm{sc}}$ compared to the base line case. Although FF is smaller than base line case because of the high difference between $\mathrm{J}_{\mathrm{sc}}$ and maximum current of the cell, the important parameters of the solar cell are much more than base line case. Figure 4 and Figure 5 show the characteristics of the proposed cell by decreasing the cell depth.

It is clear from Figure 3, the $\mathrm{J}_{\mathrm{sc}}$ decreases and $\mathrm{V}_{\mathrm{oc}}$ increases by reducing the depth. Therefore, cell has a lower FF. Moreover, the variation of the $J_{s c}$ in the lower depth is higher than large depth. Figure 6 shows the cell efficiency and FF of the proposed structure as a function of depth. Because of reducing the depth corresponding to a thinner cell, photogeneration rate decreases. As a result, the efficiency of the cell is decreased. It can be seen from Figure 5 by decreasing the depth up to 0.1 , the cell efficiency is still better than base line case. 


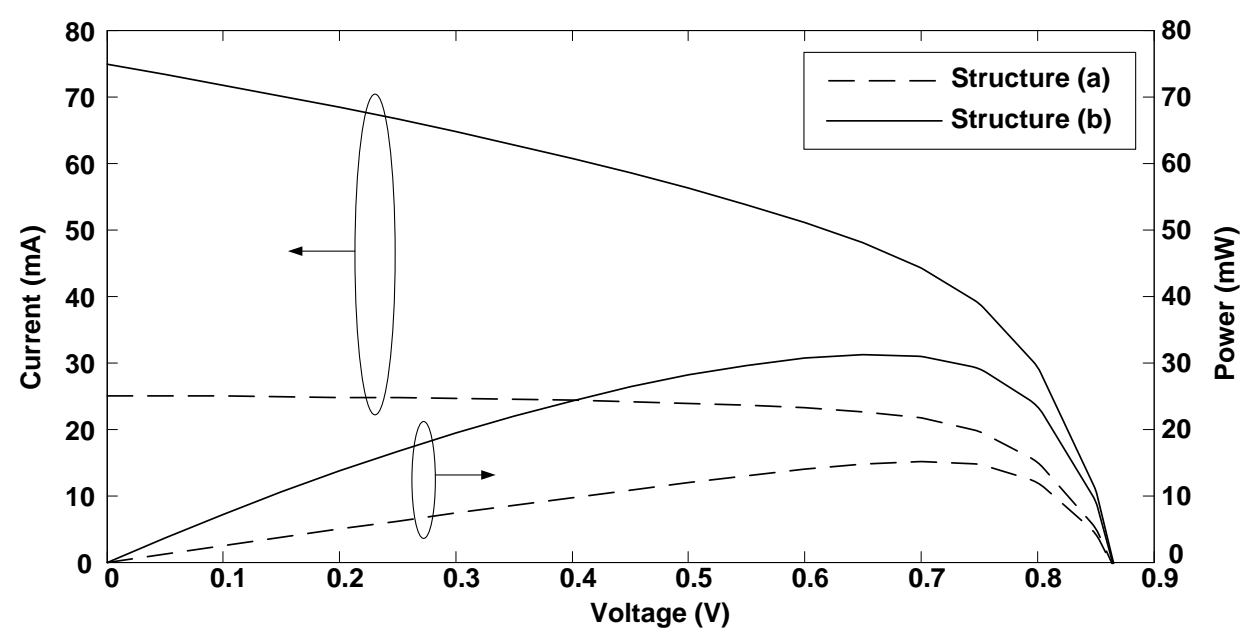

Figure 3. Characteristics of the (a) baseline case structure and (b) modified cell structure for higher efficiency.

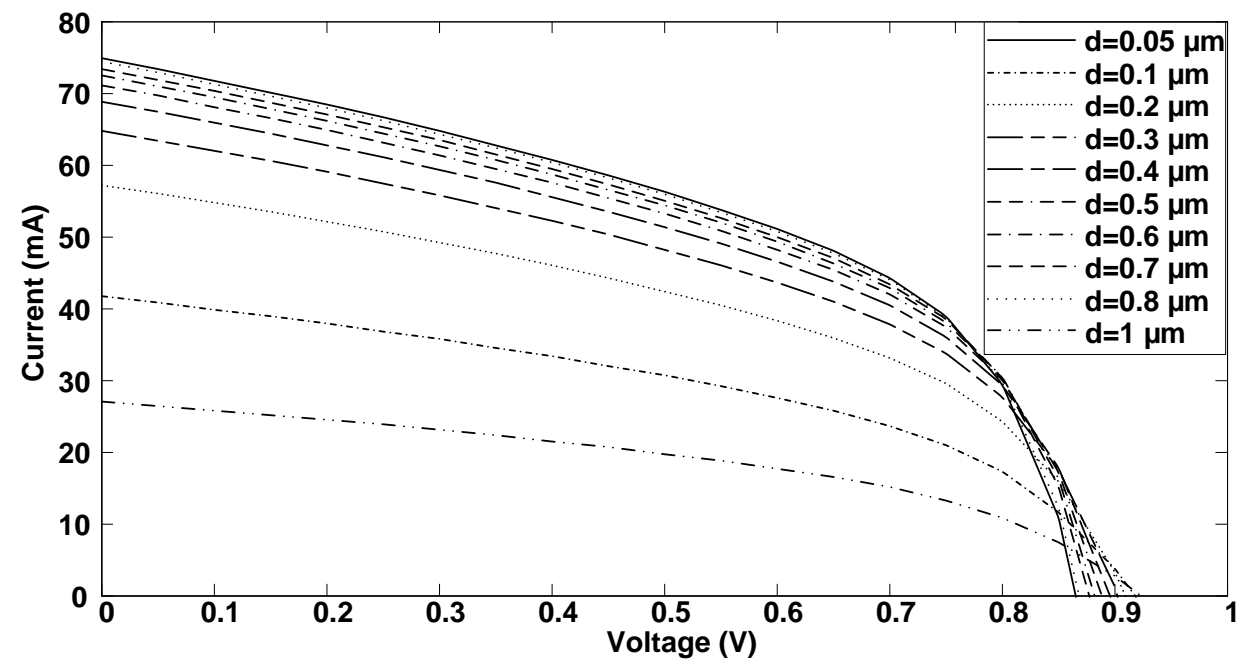

Figure 4. Light J-V curves of the cell with the lower depth (d).

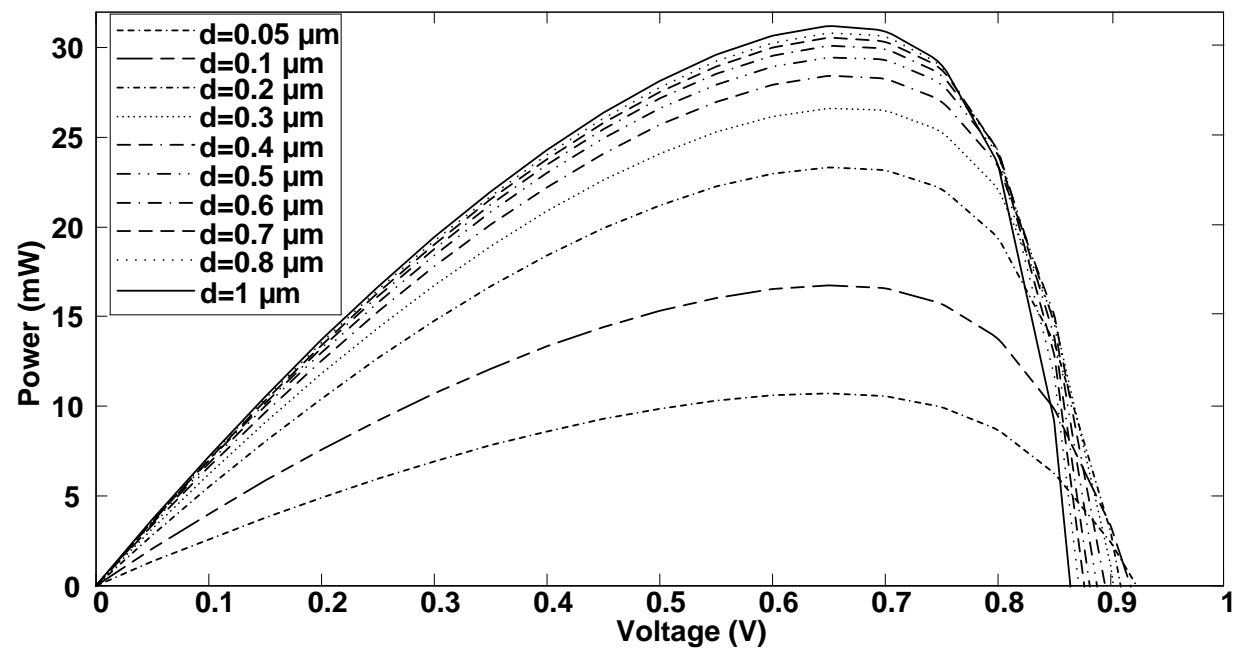

Figure 5. Power curves of the cell with the lower depth (d). 


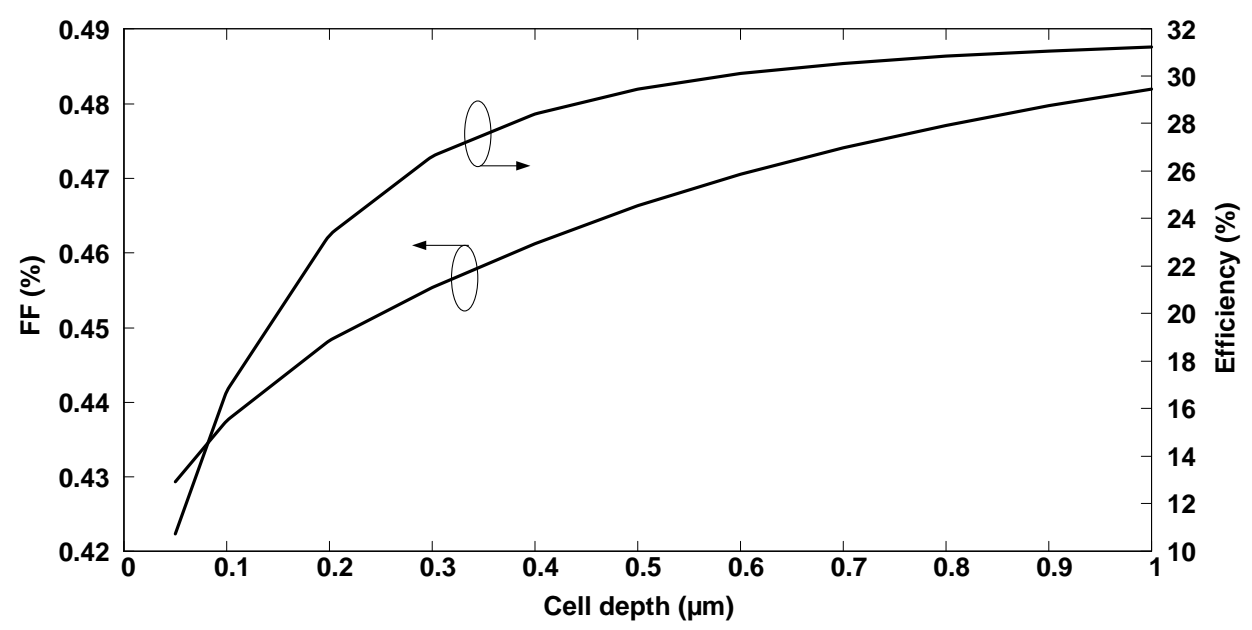

Figure 6. Efficiency and FF of the cell as a function of the cell depth.

\section{Results and Discussion}

The CdTe absorber thickness have to decreases below the absorption limit of $1 \mu \mathrm{m}$ in order to reduce material usage and to address carrier recombination loss throughout the absorber layer. Generally, the absorber layer thickness in thin film CdTe solar cells is between 2 and $10 \mu \mathrm{m}$. In order to avoid pinholes reaching through to the window layer, thicker absorber layers are used that may lead to shorting from the back contact. Cell performance depends on CdTe thickness and the magnitude of photocurrent generation loss, especially for the very thin CdTe layers. Decreasing the CdTe thickness would minimize series resistance as well as cost of the material. As mentioned above, if the absorber layer is reduced, the carrier generation relative to less absorption would be low and vice versa.

Figure 7 and Figure 8 show the characteristics of the proposed structure for the various thickness of the CdTe layer. As it is shown by Figure 6, $\mathrm{J}_{\mathrm{sc}}$ is considerably decreased by decreasing the thickness of the CdTe layer due to reduced photon absorption resulting to a lower photocurrent and it is negligible by increasing the thickness. The $\mathrm{V}_{\mathrm{oc}}$ is increased with absorber thickness, due to an increase in the photogenerated current as the absorption volume is increased. Because the generated carriers by incident photons must travel through the CdTe thickness and they experience a high series resistance to arrive to the back contact, CdTe thickness increment is limited. Thus, the current density is decreased resulting to low cell efficiency.

In the proposed structure, the simulation results showed that for a CdTe thickness more than a critical value, the efficiency was decreased. Thus, increase of efficiency by thickness is limited by a maximum value. Figure 9 shows the variation of efficiency and FF as a function of CdTe thickness. As shown in Figure 9, the efficiency is decreased when the CdTe thickness is reduced. The reason is the carrier generation losses. The FF can be improved by reducing the thickness of CdTe absorber material. As a result, $\mathrm{J}_{\mathrm{sc}}$ and $\mathrm{V}_{\mathrm{oc}}$ are decreased and the FF is increased.

In this section the effect of CdTe doping on the important parameters of CdTe solar cell is studied. If the doping of the CdTe is decreased, the absorption and the percent of the light arriving to the CdTe layer converting to the current would be decreased. Therefore, current density is decreased resulting in a loss in efficiency. The $\mathrm{V}_{\text {oc }}$ of the cells can be improved by higher carrier density of CdTe $\left(\sim 10^{15} \mathrm{~cm}^{-3}\right)$ and higher absorber lifetime (>1 ns) and reducing the back contact barrier height. So, product of $\mathrm{J}_{\mathrm{sc}}$ and $\mathrm{V}_{\mathrm{oc}}$ becomes low resulting in a high FF. Figure 10 and Figure 11 show the characteristics of the proposed structure as a function of CdTe doping variation.

Figure 12 shows the FF and efficiency of the proposed structure as a function of CdTe doping. As mentioned above, CdTe decrement results in a lower efficiency and higher FF.

\section{Conclusion}

In this paper, a new structure of CdS/CdTe solar cell is proposed which is achieved by rotating $90^{\circ}$ in the base line structure. The result showed a considerable improvement over the $15 \%$ efficiency of the reference solar cell. 


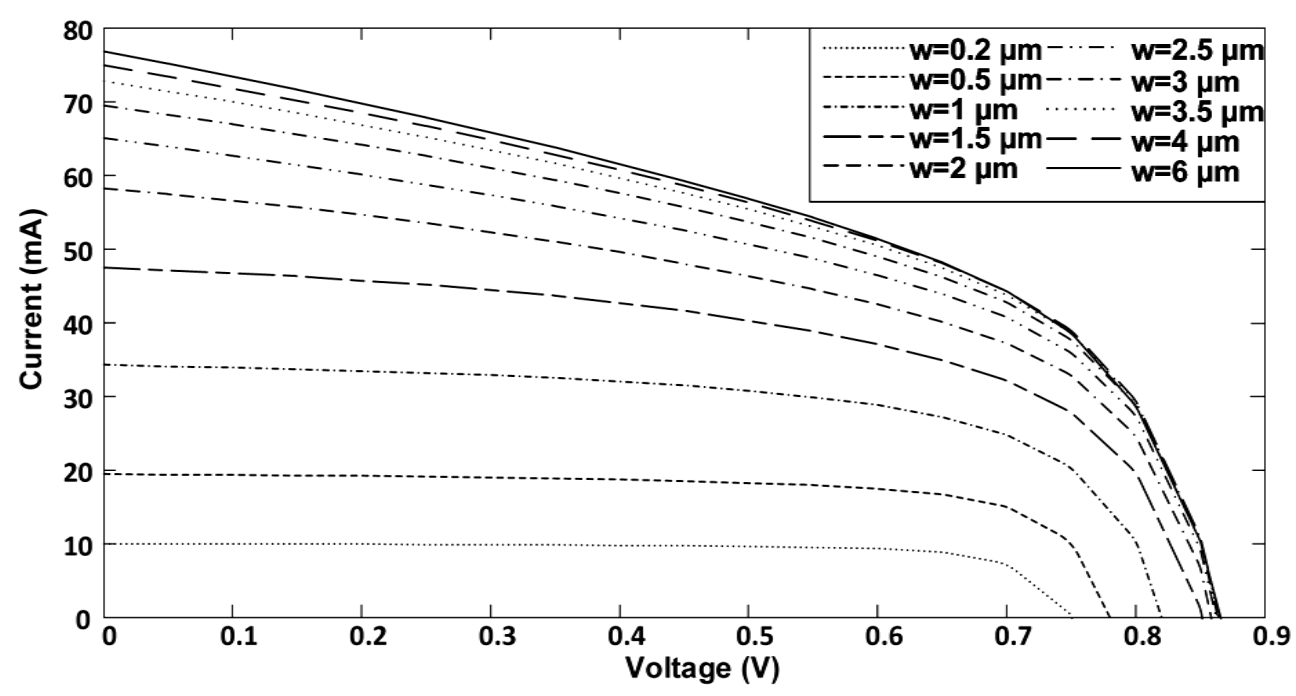

Figure 7. Light J-V curves of the cell with the lower CdTe thickness.

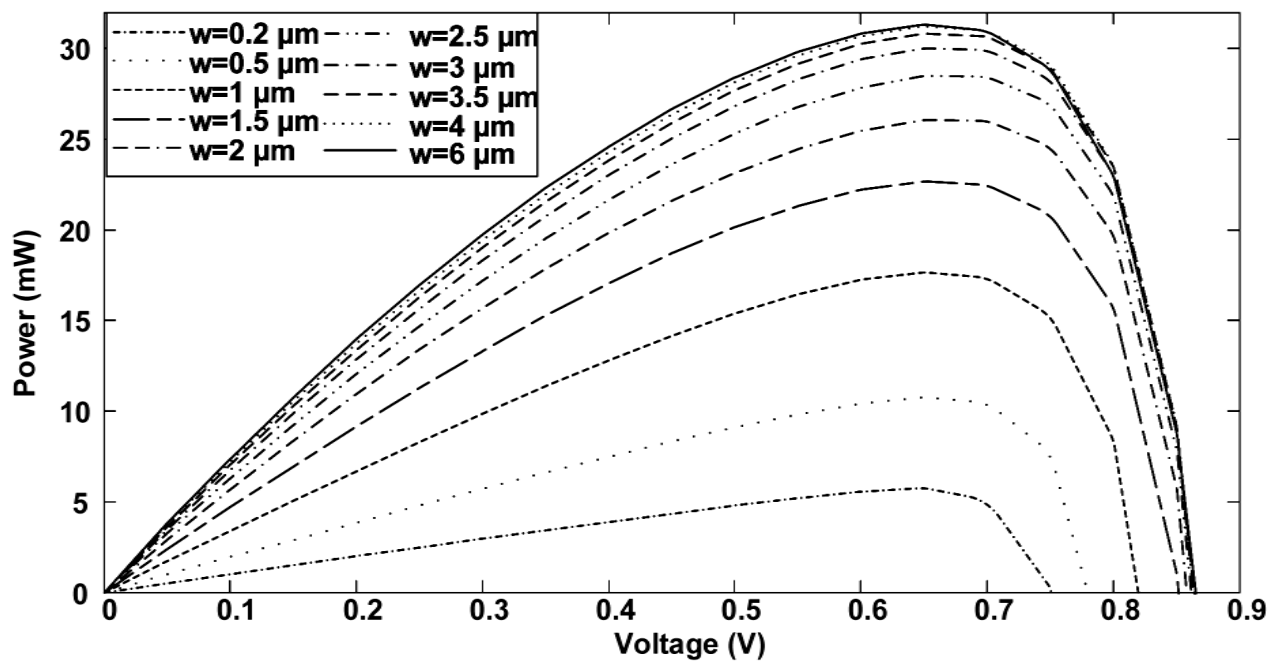

Figure 8. Power curves of the cell with the lower CdTe thickness.

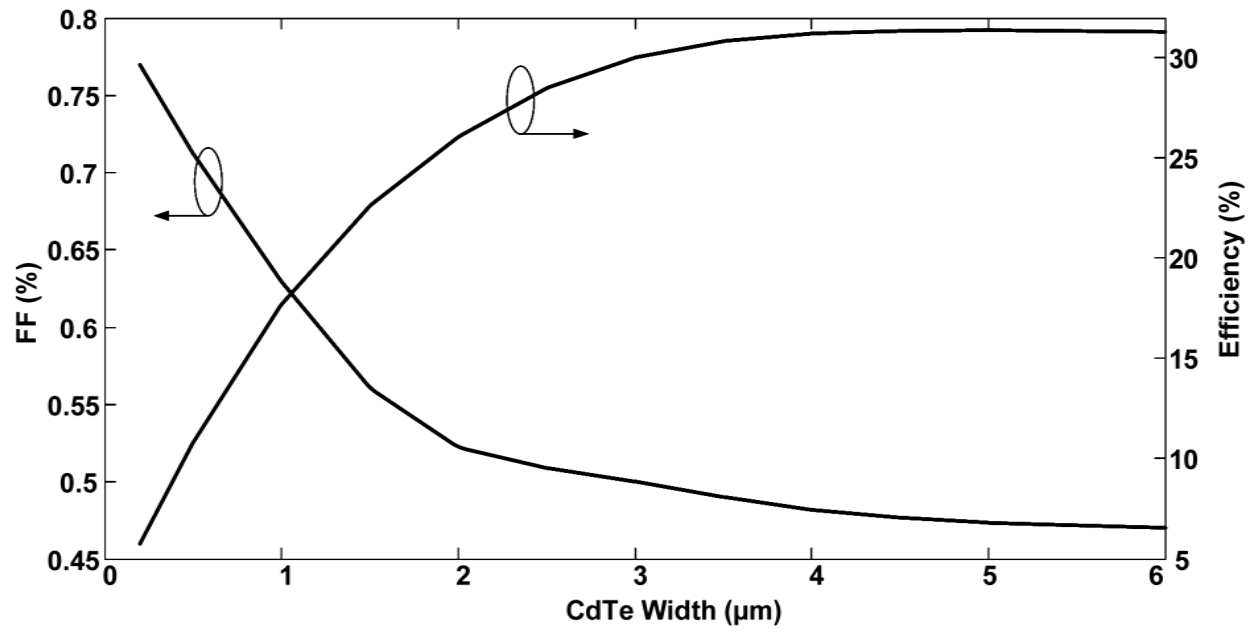

Figure 9. Efficiency and FF of the cell as a function of the CdTe thickness. 


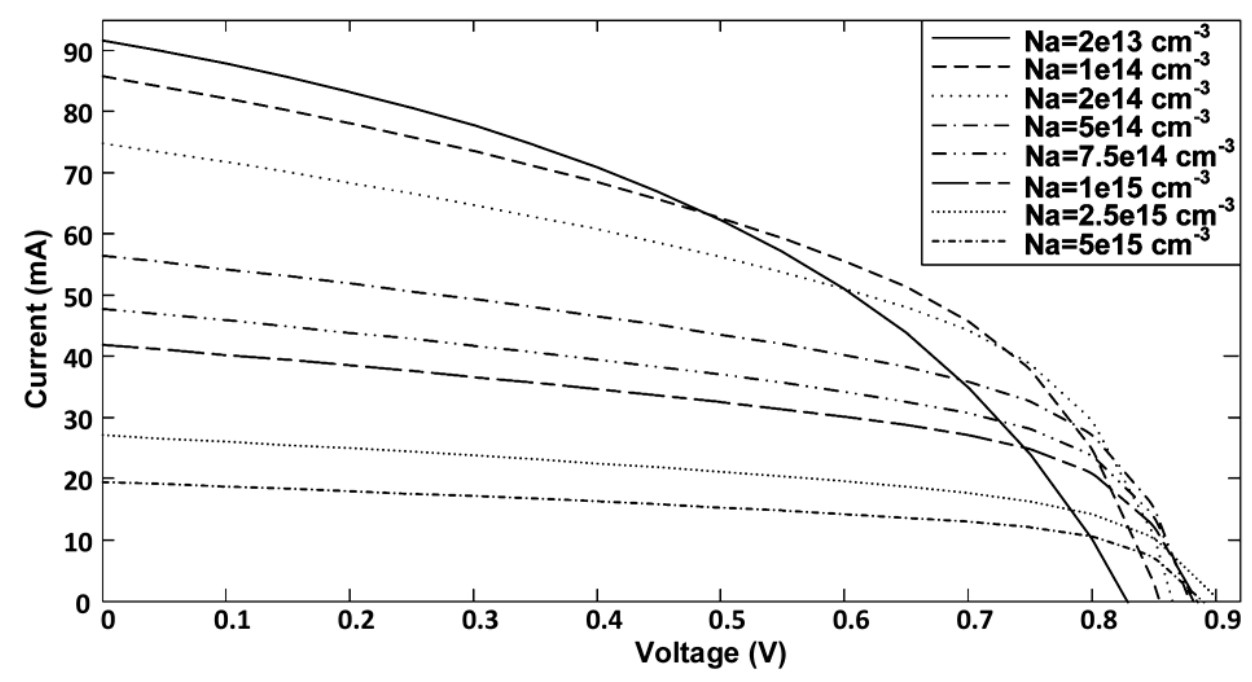

Figure 10. Light J-V curves of the cell with different CdTe doping.

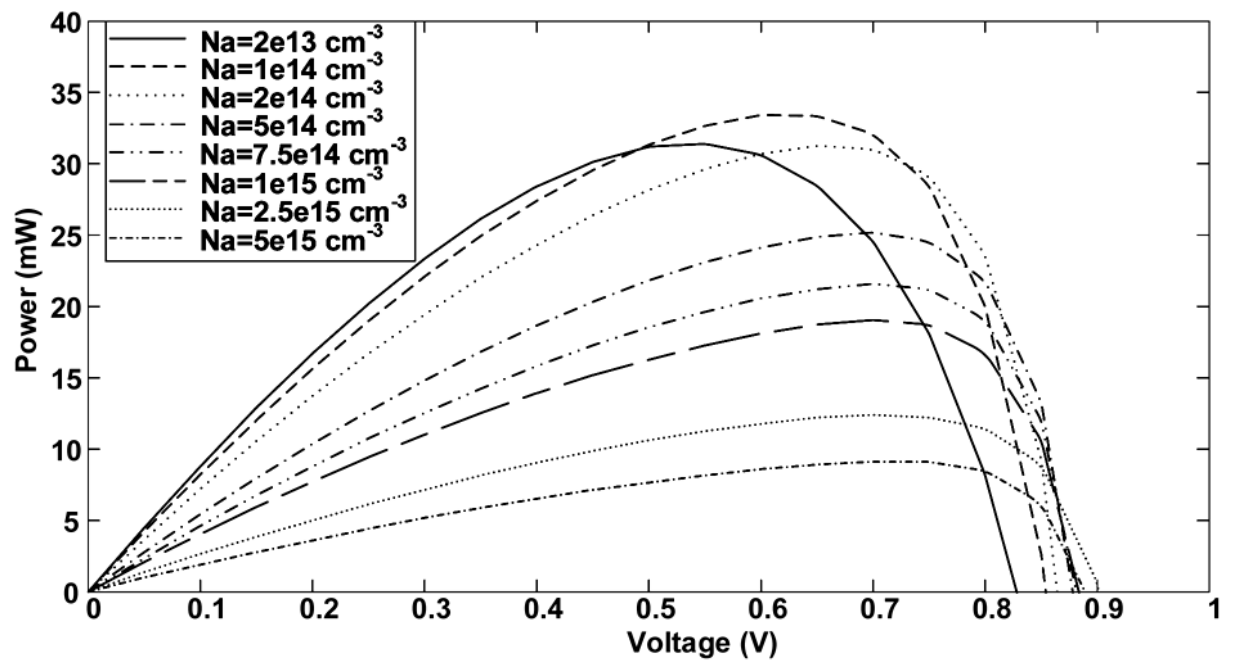

Figure 11. Power of the cell different CdTe doping.

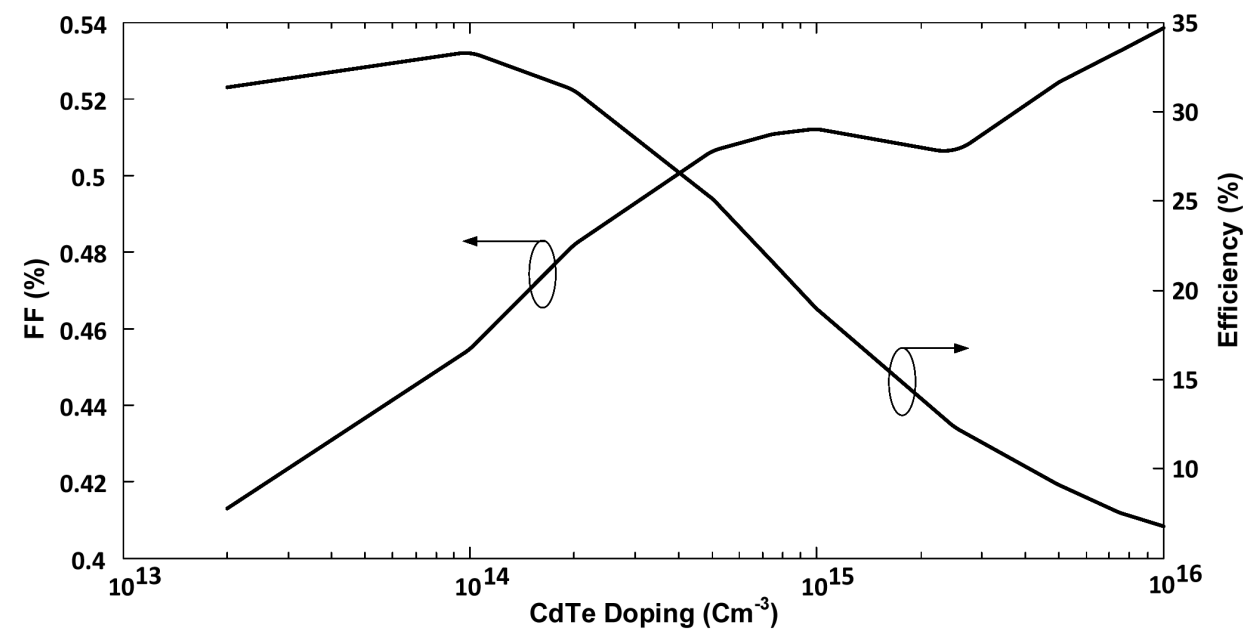

Figure 12. Efficiency and FF of the cell as a function of the CdTe doping. 
This structure showed acceptable efficiency which is quite noteworthy in reducing the amount of material used and associated losses. It was shown that $0.1 \mu \mathrm{m}$ of CdTe absorber layer was sufficient to produce conversion efficiency over $15 \%$. The proposed cell had a $\mathrm{V}_{\mathrm{oc}}$ of $866 \mathrm{mV}$, a $\mathrm{J}_{\mathrm{sc}}$ of $74.84 \mathrm{~mA} / \mathrm{cm}^{2}$, and a $\mathrm{FF}$ of $48.2 \%$, corresponding to a conversion efficiency of $31.2 \%$ under global AM 1.5 conditions.

\section{References}

[1] Khosroabadi, S., Keshmiri, S.H. and Marjani, S. (2014) Design of a High Efficiency CdS/CdTe Solar Cell with Optimized Step Doping, Film Thickness, and Carrier Lifetime of the Absorption Layer. Journal of the European Optical Society, 9, 14052-1-14052-6. http://dx.doi.org/10.2971/jeos.2014.14052

[2] Khosroabadi, S. and Keshmiri, S.H. (2014) Design of a High Efficiency Ultrathin CdS/CdTe Solar Cell Using Back Surface Field and Backside Distributed Bragg Reflector. Optics Express, 22, A921-A929. http://dx.doi.org/10.1364/OE.22.00A921

[3] Sabaghi, M., Majdabadi, A. Marjani, A. and Khosroabadi, S. (2015) Optimization of High-Efficiency CdS/CdTe Thin Film Solar Cell Using Step Doping Grading and Thickness of the Absorption Layer. Oriental Journal Of Chemistry, 31, 891-896. http://dx.doi.org/10.13005/ojc/310232

[4] Sabaghi, M., Majdabadi, A., Khosroabadi, S. and Marjani, S. (2015) A Novel Ultrathin CdS/CdTe Solar Cell with Conversion Efficiency of $31.2 \%$ for Nano-Area Application. Proceedings of the Progress in Electromagnetics Research Symposium (PIERS), Prague, Czech Republic, 6-9 July 2015, 1152-1155.

[5] Hana, J., Liaoa, C., Jianga, T., Spanheimerb, C., Haindlb, G., Fub, G., Krishnakumarb, V., Zhaoa, K., Kleinb, A. and Jaegermannb, W. (2011) An Optimized Multilayer Structure of CdS Layer for CdTe Solar Cells Application. Journal of Alloys and Compounds, 509, 5285-5289. http://dx.doi.org/10.1016/j.jallcom.2010.12.085

[6] Krishnakumar, L.V., Han, J., Klein, A. and Jaegermann, W. (2011) CdTe Thin Film Solar Cells with Reduced CdS Film Thickness. Thin Solid Films, 519, 7138-7141. http://dx.doi.org/10.1016/j.tsf.2010.12.118

[7] Meyers, P.V. and Albright, S.P. (2000) Technical and Economic Opportunities for CdTe PV at the Turn of the Millennium. Progress in Photovoltaics: Research and Applications, 8, 161-169. http://dx.doi.org/10.1002/(SICI)1099-159X(200001/02)8:1<161::AID-PIP307>3.0.CO;2-A

[8] Bonnet, D. (2003) CdTe Thin-Film PV Modules. In: Practical Handbook of Photovoltaic: Fundamentals and Applications, Elsevier, Oxford, 333-366. http://dx.doi.org/10.1016/B978-185617390-2/50015-5

[9] Green, M.A., Emery, M.A., Hishikawa, Y., Warta, W. and Dunlop, E.D. (2011) Solar Cell Efficiency Tables (Version 38). Progress in Photovoltaics: Research and Applications, 19, 84-92. http://dx.doi.org/10.1002/pip.1088

[10] Kosyachenko, L.A., Savchuk, A.I. and Grushko, E.V. (2009) Dependence of Efficiency of Thin-Film CdS/CdTe Solar Cell on Parameters of Absorber Layer and Barrier Structure. Thin Solid Films, 517, 2386-2391. http://dx.doi.org/10.1016/j.tsf.2008.11.012

[11] Britt, J. and Ferekides, C. (1993) Thin Film CdS/CdTe Solar Cell with 15.8\% Efficiency. Applied Physics Letters, 62, 2851-2852. http://dx.doi.org/10.1063/1.109629

[12] Pena, J.L., Ares, O., Rejon, V., Rios-Flores, A., Camacho, J.M., Romeo, N. and Bosio, A. (2011) A Detailed Study of the Series Resistance Effect on CdS/CdTe Solar Cells with Cu/Mo Back Contact. Thin Solid Films, 520, 680-683. http://dx.doi.org/10.1016/j.tsf.2011.04.193

[13] Colegrove, E., Banai, E., Blissett, E., Buurma, E., Ellsworth, E., Morley, M., Barnes, M., Gilmore, C., Bergeson, J.D., Dhere, R., Scott, R., Gessert, R. and Sivananthan, S. (2012) High-Efficiency Polycrystalline CdS/CdTe Solar Cells on Buffered Commercial TCO-Coated Glass. Journal of Electronic Materials, 41, 2833-2837. http://dx.doi.org/10.1007/s11664-012-2100-z

[14] Razykov, T.M., Ferekides, T.M., Morel, T.M., Stefanakos, E., Ullal, H.S. and Upadhyaya, H.M. (2011) Solar Photovoltaic Electricity: Current Status and Future Prospects. Solar Energy, 85, 1580-1608. http://dx.doi.org/10.1016/j.solener.2010.12.002

[15] Rios-Flores, A., Ares, O., Camacho, J.M., Rejon, V. and Pena, J.L. (2012) Procedure to Obtain Higher than 14\% Efficient Thin Film CdS/CdTe Solar Cells Activated with HCF2Cl Gas. Solar Energy, 86,780-785. http://dx.doi.org/10.1016/j.solener.2011.12.002

[16] Kanevce, A. and Gessert, T.A. (2011) Optimizing CdTe Solar Cell Performance: Impact of Variations in Minority-Carrier Lifetime and Carrier Density Profile. IEEE Journal of Photovoltaics, 1, 99-103. http://dx.doi.org/10.1109/JPHOTOV.2011.2164952

[17] Wu, X., Keane, J.C., Dhere, R.G., DeHart, C., Albin, D.S., Duda, A., Gessert, T.A., Asher, S., Levi, D.H. and Sheldon, P. (2001) 16.5\% Efficient CdS/CdTe Polycrystalline Thin Film Solar Cell. Proceedings of the 17th Conference IEEE European Photovoltaic Solar Energy, Munich, Germany, 22-26 October 2001, 995-1000. 
[18] First Solar Inc. (2014) http://www.firstsolar.com/en/Technologies-and-Capabilities/PV-Modules/First-Solar-Series-3-Black-Module/CdTe-Te chnology.aspx

[19] Faez, R., Marjani, A. and Marjani, S. (2011) Design and Simulation of a High Power Single Mode $1550 \mathrm{~nm}$ InGaAsP VCSELs. IEICE Electronics Express, 8, 1096-1101. http://dx.doi.org/10.1587/elex.8.1096

[20] Marjani, S., Faez, R. and Hosseini, S.E. (2013) Analysis of Lattice Temperature Effects on a GaInP/6H-SiC Strained Quantum-Well Lasers. Asian Journal of Chemistry, 25, 4715-4717.

[21] Marjani, S. (2013) Various Elements of Heat Sources within an Optimized Photonic Crystal Vertical Cavity Surface Emitting Laser: Influence of Hole Etching Depth. Asian Journal of Chemistry, 25, 4153-4156.

[22] Marjani, S. (2013) Optimization of an InGaAsP Vertical-Cavity Surface-Emitting Diode Lasers for High-Power Single-Mode Operation in 1550 nm Optical-Fibre Communication Systems. Asian Journal of Chemistry, 25, 4150-4152.

[23] Marjani, S., Faez, R. and Hosseini, S.E. (2013) Threshold Characteristics Analysis of InP-Based PhC VCSEL with Buried Tunnel Junction. Proceedings of the 21st Iranian Conference on Electrical Engineering (ICEE), Ferdowsi University of Mashhad, Mashhad, Iran, 14-16 May 2013, 1-4.

[24] Naeemi, M.A., Marjani, S. and Peiravi, A. (2014) Time to Failure Analysis of Single Mode Long-Wavelength InGaAsP Vertical-Cavity Surface-Emitting Lasers. Proceedings of the 22st Iranian Conference on Electrical Engineering (ICEE), Shahid Beheshti University, Tehran, Iran, 20-22 May 2014, 43-47.

[25] Marjani, S. and Hosseini, S.E. (2015) Radio-Frequency Small-Signal Model of Hetero-Gate-Dielectric p-n-p-n Tunneling Field-Effect Transistor Including the Charge Conservation Capacitance and Substrate Parameters. Journal of Applied Physics, 118, 095708-1-095708-8. http://dx.doi.org/10.1063/1.4929361

[26] Marjani, S. and Hosseini, S. (2015) Analysis of Radio Frequency and Stability Performance on Double-Gate Extended Source Tunneling Field-Effect Transistors. Proceedings of the 23st Iranian Conference on Electrical Engineering (ICEE), Sharif University, Tehran, Iran, 10-14 May 2015, 1042-1046.

[27] Marjani, S. and Hosseini, S.E. (2014) Radio-Frequency Modeling of Square-Shaped Extended Source Tunneling Field-Effect Transistors. Superlattices and Microstructures, 76, 297-314. http://dx.doi.org/10.1016/j.spmi.2014.09.040

[28] Marjani, S. and Hosseini, S.E. (2014) A Novel Double Gate Tunnel Field Effect Transistor with 9 mV/dec Average Subthreshold Slope. Proceedings of the 22st Iranian Conference on Electrical Engineering (ICEE), Shahid Beheshti University, Tehran, Iran, 20-22 May 2014, 399-402.

[29] Marjani, S. and Hosseini, S.E. (2014) RF Modeling of p-n-p-n Double-Gate Tunneling Field-Effect Transistors. Proceedings of the Third Conference on Millimeter-Wave and Terahertz Technologies (MMWATT), Amirkabir University of Technology, Tehran, Iran, 30 December 2014-1 January 2015, 1-4.

[30] Majdabadi, A., Marjani, A. and Sabaghi, M. (2014) Threshold Characteristics Enhancement of a Single Mode $1.55 \mu \mathrm{m}$ InGaAsP Photonic Crystal VCSEL for Optical Communication Systems. Optics and Photonics Journal, 4, 296-303. http://dx.doi.org/10.4236/opj.2014.410029 